\title{
Effects of food supplementation on litter size and oestradiol concentration during gestation and oestrous cycle of capybaras (Hydrochaeris hydrochaeris) in captivity
}

\author{
G. K. Becker, G. C. Pederassi, E. A. Santos and E. P. Colares* \\ Programa de Pós-graduação em Fisiologia Animal Comparada, Departamento de Ciências Fisiológicas, \\ Fundação Universidade Federal do Rio Grande, Cx. Postal 474 CEP 96201-900, Rio Grande, RS, Brazil
}

The present study analysed the response of adult female capybaras (Hydrochaeris hydrochaeris) to different dietary supplementation in relation to litter size per parturition and oestradiol secretion profile during pregnancy and the oestrous cycle. All four experimental groups received 'camerum' grass (Pennisetum purpureum) and water ad libitum and three of the groups were also fed a protein, lipid or protein and lipid supplement. Litter size per parturition did not show any significant difference among treatment groups, but was significantly higher $(P<0.05)$ than in the control group. There was no significant difference in oestradiol concentrations among treatments and the control group, during each phase of the oestrous cycle or during gestation. The average oestradiol concentrations in dioestrous, oestrous and metoestrous phases were not significantly different from each other, but were significantly lower $(P<0.05)$ than the average oestradiol concentration in the pro-oestrous phase. In addition, average oestradiol concentrations increased after the second gestation month, but were significantly higher $(P<0.05)$ only after the fourth gestation month, achieving maximum value by the end of gestation. Dietary supplementation had no significant effect on hormonal concentrations during the oestrous cycle and gestational period. However, an increase in litter size per parturition was observed among female capybaras that received dietary supplementation.

\section{Introduction}

It has been suggested that food acts on the endocrine control of reproduction by changing the hypothalamushypophysis-gonad system (Bronson, 1989; Bronson and Heideman, 1990, 1994; Blache et al., 2000). Food supplementation causes an increase in reproductive capacity in several rodents (Watts, 1970; Smith, 1971; Cole and Batzli, 1978; Boutin, 1990; Akbar and Gorman, 1993a,b, 1996; Colares, 1997). In mild winters or with the provision of food supplementation there is an increase in the number of pregnant female rodents in fields in Argentina (Mills et al., 1992; Cittadino et al., 1994).

According to Thomas et al. (1997), the consumption of polyunsaturated fatty acids causes a greater rate of ovarian follicular growth in cattle, which can lead to an increase in oestradiol concentrations. The provision of higher protein content forage and vegetable oils results in an increase in ovulation rate and reproductive efficiency in sheep (Luque et al., 2000). Protein supplementation increases the release of LH in cattle (Kane et al., 2002).

*Correspondence

Email: ecolares@octopus.furg.br
Capybaras (Hydrochaeris hydrochaeris) are found in Central and South America, from Panama to Northern Argentina (Alho and Rondon, 1987; Emmons, 1990). They are herbivorous animals and are found close to water courses with abundant vegetation, where they form family groups (Emmons, 1990). Capybaras are the largest rodent, weighing up to $70 \mathrm{~kg}$. They are annual polyestrous animals, with spontaneous ovulation and an oestrous cycle of 8 days, and a receptivity period of at least $8 \mathrm{~h}$ (López, 1982). The gestation period of capybaras is $150.6 \pm 2.8$ days (López, 1987); average litter size is four per parturition and lactation lasts 4 months (Zara, 1973). In the Pantanal (Brazil), reproduction takes place all year round, but peaks among young animals from July to August, when plant production is greatest (Alho and Rondon, 1987). However, in captivity, the reproductive capacity of capybaras is related to the size of paddocks and the quantity and quality of the diet (Andrade et al., 1998).

From evidence linking nutritional aspects to reproductive processes in different rodent species and other mammals, the present study analysed the response of adult female capybaras to different dietary supplementation in relation to litter size per parturition and the oestradiol hormone secretion profile during pregnancy and the oestrous cycle. 
Table 1. Composition of supplementation diet offered to capybaras (Hydrochaeris hydrochaeris) during the experimental period

\begin{tabular}{lrrrrrr}
\hline & \multicolumn{1}{c}{$\begin{array}{c}\text { Protein Lipids Carbohydrates } \\
(\%)\end{array}$} & $\begin{array}{r}\text { Ash } \\
(\%)\end{array}$ & \multicolumn{1}{c}{$\begin{array}{c}\text { Moisture } \\
(\%)\end{array}$} & $\begin{array}{c}\text { Crude } \\
\text { energy } \\
\left(\mathrm{Kcal} \mathrm{kg}^{-1}\right)\end{array}$ \\
\hline Grass & 8.0 & 1.8 & 68.6 & 10.5 & 11.1 & 3763.9 \\
Treatment 1 & 12.1 & 4.5 & 51.5 & 8.3 & 23.6 & 2929.8 \\
Treatment 2 & 8.2 & 22.5 & 54.5 & 6.5 & 8.3 & 3848.2 \\
Treatment 3 & 10.9 & 24.1 & 47.4 & 6.6 & 10.9 & 3877.6 \\
\hline
\end{tabular}

The four experimental groups each received camerum grass and water ad libitum and three of the groups also received a $500 \mathrm{~g}$ supplement of protein (treatment 1), lipids (treatment 2), or protein and lipids (treatment 3 ).

\section{Materials and Methods}

\section{Animals}

Forty-eight healthy, non-pregnant female capybaras (Hydrochaeris hydrochaeris), aged 3-6 years, average $67.6 \pm 0.72 \mathrm{~kg}$ body weight, were obtained from a breeding facility located close to the city of Santo Antônio da Patrulha, Rio Grande do Sul State, Brazil. These animals were fed with elephant grass of the camerum variety (Pennisetum purpureum) and water ad libitum. The experiment began in spring (November). The animals were divided into four treatment groups, two families of capybaras per treatment, containing one male and six females, and were kept in 0.8 hectare paddocks with natural lighting. Each paddock had a 0.1 hectare pool and a covered area for food administration. All animal procedures were approved by the collegiate of the Department of Physiological Sciences, Fundação Universidade Federal do Rio Grande.

\section{Food supplementation}

Barley roots (14\% protein) and corn oil were used as dietary supplements. The choice of the supplement and the calculation of the amount of food supplied was based on the scheme used by the owner of the breeding facility. Camerum grass was chosen as the main forage as it was already available at the breeding facility and because of results from previous studies (Parra et al., 1978; Baldizan et al., 1986; Max et al., 1993).

The animals were fed camerum grass ad libitum each morning. Of the eight groups two were fed grass only, and the other six (two groups per treatment) were given 500 $\mathrm{g}$ of food supplement per animal (Table 1). The animals ate all supplementation before grass was administered.

\section{Determining pregnancy and litter size per parturition}

The animals were weighed every 2 months. Changes in body weight that followed a growing and gradual trend were taken as signs of pregnancy and sudden falls in weight were taken as the occurrence of parturition. In addition, paddocks were inspected on a daily basis for parturition and the number of offspring was noted.

\section{Blood collection}

After being weighed, blood was collected from the saphenous vein on the cranial branch with a disposable syringe and 'scalp' needle G19. The blood was placed in a test tube without anticoagulant and centrifuged for $20 \mathrm{~min}$ at $2000 \mathrm{~g}$. The serum was then transferred to a freezing tube and stored at $-20^{\circ} \mathrm{C}$ for later hormone analysis.

\section{Colpocytology}

Samples of vaginal mucosa sloughing were collected with a swab moisturized with saline. Smears were made on microscope slides, fixed in absolute alcohol and then stained by the Shorr method (Arruda et al., 1976). The smear was examined using $a \times 100$ magnification microscope for the presence and number of cells (Lópes, 1982) to determine the phase of the oestrous cycle.

\section{Oestradiol assay}

Oestradiol assay measurement was made in duplicate using reagent kits $\left(\mathrm{ICN}^{\circledR}\right.$ Biomedicals Inc., Costa Mesa, CA) of radioimmunoassay in solid phase. Readings were made for $1 \mathrm{~min}$ in a gamma counter (Countrate Computer P-30A, GAMMA TOM ${ }^{\circledR}$ ). Measurement accuracy was assessed using the formula of Cook and Beastall (1987).

Standard curves to determine serum concentrations of oestradiol were constructed using the 'Immunoassay Calibration Curve and Sample Calculation' program written in Basic by R. Roberts and K. Warren (University of Florida).

\section{Statistical analysis}

Data on oestradiol serum concentrations in capybaras during the oestrous cycle were analysed by two-way ANOVA and data on litter size per parturition were analysed by one-way ANOVA. Oestradiol serum concentrations during gestation were analysed by repeated measure ANOVA. Analyses were followed by Tukey's multiple range test (Statistica for Windows 4.3, StatSoft Inc., 1993). The level of significance used was 5\%. ANOVA assumptions (homocedasticity and normality) had been tested previously.

\section{Results}

Litter size per parturition did not show any significant difference among the groups fed dietary supplementation, 
Table 2. Litter size per parturition in each treatment group of capybaras (Hydrochaeris hydrochaeris)

\begin{tabular}{lcc}
\hline Group & Number of parturitions & Litter size per parturition \\
\hline Control & 5 & $2.20 \pm 0.37^{\mathrm{a}}$ \\
Treatment 1 & 8 & $4.36 \pm 0.48^{\mathrm{b}}$ \\
Treatment 2 & 12 & $4.29 \pm 0.42^{\mathrm{b}}$ \\
Treatment 3 & 9 & $4.00 \pm 0.22^{\mathrm{b}}$ \\
\hline
\end{tabular}

The four experimental groups each received camerum grass and water ad libitum and three of the groups also received a $500 \mathrm{~g}$ supplement of protein (treatment 1), lipids (treatment 2), or protein and lipids (treatment 3 ).

Same letters in the same column indicate homogeneous groups $(P>0.05)$

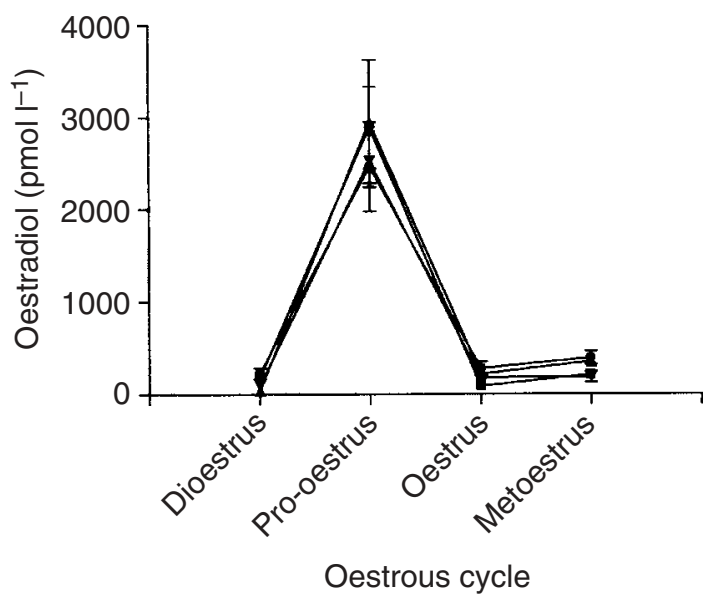

Fig. 1. Means and standard error of oestradiol concentration during the oestrous cycle of capybaras (Hydrochaeris hydrochaeris), subject to food supplementation. The four experimental groups each received camerum grass and water ad libitum and three of the groups also received a supplement. $\bullet$ : control; $\mathbf{\square}$ : treatment 1 , $500 \mathrm{~g}$ protein supplement; $\mathbf{\Delta}$ : treatment 2, $500 \mathrm{~g}$ lipid supplement; $\mathbf{\nabla}$ : treatment 3, $500 \mathrm{~g}$ protein and lipid supplement.

but was significantly higher $(P<0.05)$ than in the control group (Table 2).

No significant difference was detected in oestradiol concentrations among the treatment and control groups during each phase of the oestrous cycle (Fig. 1). In addition, average oestradiol concentrations in the dioestrous, oestrous and metoestrous phases did not show any significant difference from each other, but were significantly lower $(P<0.05)$ than the average oestradiol concentration in the pro-oestrous phase.

There was no significant difference in average oestradiol concentrations among the treatment and control groups during gestation (Fig. 2). However, average oestradiol concentrations increased during gestation and can be expressed either as a linear $(F=55.57 ; P=0.0000)$ or quadratic equation $(\mathrm{F}=7.35 ; P=0.0168)$.

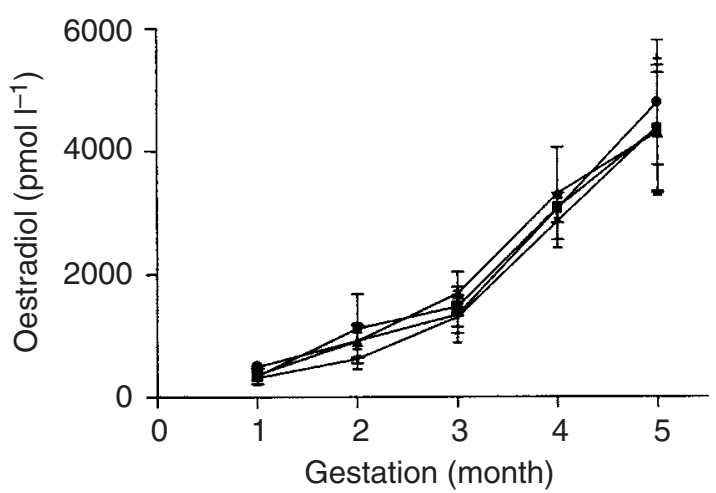

Fig. 2. Means and standard error of oestradiol concentration during gestation of capybaras (Hydrochaeris hydrochaeris), subject to food supplementation. The four experimental groups each received camerum grass and water ad libitum and three of the groups also received a supplement. @: control; $\mathbf{\square}$ : treatment 1, $500 \mathrm{~g}$ protein supplement; $\mathbf{\Lambda}$ : treatment 2, $500 \mathrm{~g}$ lipid supplement; $\mathbf{\nabla}$ : treatment 3, $500 \mathrm{~g}$ protein and lipid supplement.

\section{Discussion}

Variations in reproduction in many mammals are caused by changes in the quantity and quality of food the animals find in their environment (Flowerdew, 1987; Bronson, 1989). Food restriction can result in delay of the onset of sexual maturity, suppression of the oestrous cycle, uterus atrophy, resorption of embryos during gestation, decrease in milk production and changes in reproductive hormone concentrations (Long et al., 1999; Blache et al., 2000; Angel-Meza et al., 2001; Kusina et al., 2001). However, food supplementation can improve reproductive capacity in animals, promoting earlier onset of sexual maturity, oestrous cycle activation, increase in milk production, increase in reproductive hormone concentrations and increase in litter size per parturition (Colares, 1997; Long et al., 1999; Kusina et al., 2001).

Watts (1970) studied the variation in the duration of reproductive period in relation to food availability in Clethrionomys glareolus and Apodemus sylvaticusi, and found that food supplementation does not alter the reproductive period. However, in optimal environmental conditions and optimal food supply, capybaras breed twice per year (Ojasti, 1972). Mills et al. (1992) found that during summer and mild winters there is an increase in the number of pregnant females of Calomys laucha, C. musculinus and Akodon azarae rodents in cereal fields in Argentina, which may be related to an increase in food supply.

Food supplementation using rabbit feed increases the reproductive capacity of the mouse Microtus ochrogaster but cannot prevent a decline during the non-reproductive period (Cole and Batzli, 1978). This is also the case for other rodents (Watts, 1970; Smith, 1971; Boutin, 1990; Akbar and Gorman, 1993a,b, 1996). However, the reproductive capacity of the rodent Calomys laucha 
is increased in winter when the diet is supplemented with sunflower seeds, compared with non-supplemented animals (Colares, 1997).

Mammals require a balanced diet for reproduction, and minimum amounts of proteins and fats are necessary (Sadleir, 1969; Flowerdew, 1987; Bronson, 1989; Trujillo and Broughton, 1995). Colares (1997) determined that dietary supplementation with sunflower seeds increases litter size per parturition and the number of parturitions in the rodent Calomys laucha and suggested that these increases are due to the content of fatty acids and essential amino acids in sunflower seeds. Studies with laboratory rats have shown that food supplementation with corn oil can increase reproduction (Soares, 1992). Lipids in general cause an increase in reproductive capacity in ruminants by influencing follicular growth and corpus luteum function (Mattos et al., 2000). Increased protein content in the diet (8\%, $16 \%$ or $24 \%$ ) results in earlier sexual maturation in young females and an increase in litter size per parturition in the mouse Mus musculus (Vandenbergh et al., 1972). A minimum of $7.5 \%$ protein per dry weight of food is critical for reproduction in the rat Sigmodon hispidus (Randolph et al., 1995). Similar results have been found for other rodents by Donald et al. (1981), Batzli (1986) and Angel-Meza et al. (2001).

The present study found that food supplementation results in an increase in the reproductive performance of female capybaras. Female Calomys laucha also have increased parturitions and significantly smaller litter sizes when subjected to food restriction and larger litter sizes when fed sunflower seeds (Colares, 1997). Colares (1997) has suggested that this decrease in the reproductive capacity of animals subjected to food restriction may be due to a decrease in follicular development or to resorption of embryos early in gestation. Bronson and Marsteller (1985) also found that food restriction can cause resorption of embryos during gestation and that the number of resorptions is directly proportional to food restriction. The authors of the present study believe that the same may occur in capybaras.

A $50 \%$ reduction in food causes a decrease in the concentration of LH in the blood in rats (Howland, 1971) and other mammal species (Thong and Graham, 1999). This decrease in LH is due to a failure in the release of this hormone by the hypophysis, which may influence oestradiol concentrations, compromising the ovulation process (Thong and Graham, 1999). In addition, a $48 \mathrm{~h}$ fasting period on the first day of the oestrous cycle in hamsters results in a decrease in serum oestradiol concentrations, causing suppression of the oestrous cycle (Morin, 1986).

Despite the smaller litter size in control animals in the present experiment, the absence of food supplementation did not cause any variation in oestradiol concentrations in supplemented or control animals, both during the oestrous cycle and during gestation. It is probable that the group of control capybaras that became pregnant were in good nutritional status, and this enabled an oestradiol production similar to that of supplemented animals. This contention is in agreement with Schneider et al. (2000), who found that animals that receive a low quality or quantity of food can breed if their energy storage is high.

This work was supported by FAPERGS (grant number 0102940). G. K. Becker is a fellow of Brazilian CAPES. The authors thank engineer G. de Castilho for his assistance in providing the animals.

\section{References}

Akbar Z and Gorman ML (1993a) The effect of supplementary feeding upon the sizes of the home ranges of wood mice Apodemus sylvaticus living on a system of maritime sand-dunes Journal of Zoology 231 233-237

Akbar Z and Gorman ML (1993b) The effect of supplementary feeding upon the demography of a population of wood mice Apodemus sylvaticus living on a system of maritime sand-dunes Journal of Zoology 230 609-617

Akbar Z and Gorman ML (1996) The effect of supplementary food upon the activity patterns of wood mice Apodemus sylvaticus living on a system of maritime sand-dunes Journal of Zoology 238 759-768

Alho CJR and Rondon NL (1987) Habitats, population densities and social structure of capybaras (Hydrochaeris hydrochaeris, Rodentia) in the pantanal, Brazil Revista Brasileira Zoologia 4 139-149

Andrade PCM, Lavorenti A and Filho SLGN (1998) Effects of the size of area, of the diet and of the initial age of confinement on capybaras (Hydrochoerus hydrochaeris hydrochaeris L. 1766) growth Brazilian Journal of Animal Science 27 292-299

Angel-Meza AR, Feria-Velasco A, Ontiveros-Martinez L, Gallardo L, Gonzalez-Burgos I and Beas-Zárate C (2001) Protein- and tryptophanrestricted diets induce changes in rat gonadal hormone levels Journal of Nutritional Biochemistry 12 192-199

Arruda OB, Tolosa EML and Neto AGF (1976) Manual de técnicas para histologia normal e patológica EDUSP, São Paulo

Baldizán A, Dixon RM and Parra R (1986) Caracteristicas de la fermentacion en el tracto gastrointestinal del Chiguire (Hydrochoerus Hydrochaeris) Informe Anual - IPA 60-61

Batzli GO (1986) Nutritional ecology of the california vole - effects of food quality on reproduction Ecology 67 406-412

Blache D, Chagas LM, Blackberry MA, Vercoe PE and Martin GB (2000) Metabolic factors affecting the reproductive axis in male sheep Journal of Reproduction and Fertility 120 1-11

Boutin S (1990) Food supplementation experiments with terrestrial vertebrates: patterns, problems, and the future Canadian Journal of Zoology 68 203-220

Bronson FH (1989) Ambient temperature and reproductive success in rodents living at different latitudes Biology of Reproduction 29 72-80

Bronson FH and Heideman PD (1990) Short-term hormonal responses to food intake in peripubertal female rats American Journal of Physiology 259 R25-R31

Bronson FH and Heideman PD (1994) Seasonal regulation of reproduction in mammals. In The Physiology of Reproduction pp 541-583 Eds E Knobil and JD Neill. Raven Press, New York

Bronson FH and Marsteller FA (1985) Effect of short-term food deprivation on reproduction in female mice Biology of Reproduction 33 660-667

Cittadino EA, Carli PDE, Busch M and Kravetz FO (1994) Effects of food supplementation on rodents in winter Journal of Mammalogy 75 446453

Colares EP (1997) Aspectos da Fisiologia Reprodutiva de Calomys laucha Olfers, 1818 (mammalia: rodentia) Tese de doutorado Universidade de São Paulo

Cole FR and Batzli GO (1978) Influence of supplemental feeding on a vole population Journal of Mammalogy 59 809-819 
Cook B and Beastall GH (1987) Measurement of steroid hormone concentrations in blood, urine and tissues. In Steroid Hormones, A Practical Approach pp 1-65 Eds B Green and RE Leake. IRL Press Limited, Oxford

Donald P, Pitts GC and Pohl SL (1981) Body-weight and composition in laboratory rats - effects of diets with high or low protein concentrations Science 211 185-186

Emmons LH (1990) Neotropical Rainforest Mammals: A Field Guide The University of Chicago Press, Chicago

Flowerdew JR (1987) Mammals. Their Reproductive Biology and Population Ecology Edward Arnold Ltd, London

Howland BE (1971) Gonadotrophin levels in female rats subjected to restricted feed intake Journal of Reproduction and Fertility 27 467-470

Kane KK, Creighton KW, Petersen MK, Hallford DM, Remmenga MD and Hawkins DE (2002) Effects of varying levels of undegradable intake protein on endocrine and metabolic function of young post-partum beef cows Theriogenology 57 2179-2191

Kusina NT, Chinuwo T, Hamudikuwanda H, Ndlova LR and Muzanenhamo S (2001) Effect of different dietary energy level intakes on efficiency of estrus synchronization and fertility in Mashona goats does Small Ruminant Research 39 283-288

Long RJ, Zhang DG, Wang X, Hu ZZ and Dong SK (1999) Effect of strategic feed supplementation on productive and reproductive performance in yak cows Preventive Veterinary Medicine 38 195-206

López SB (1982) Determinacion del ciclo estral en chigüires (Hydrochoerus hydrochaeris) Acta Cientifica Venezuelana 33 497-501

López SB (1987) Consideraciones generales sobre la gestacion del chigùire (Hydrochoerus hydrochaeris) Acta Cientfica Venezuelana 38 84-89

Luque A, Barry TN, McNabb WC, Kemp PD and McDonald MF (2000) The effect of grazing Lotus corniculatus during late summer-autumn on reproductive efficiency and wool production in ewes Australian Journal of Agricultural Research 51 385-392

Mattos R, Staples CR and Thatcher WW (2000) Effects of dietary fatty acids on reproduction in ruminants Reviews of Reproduction 5 38-45

Max JCM, Garrido MAO, Contiéri WA, Miras ALC and Bordin RM (1993) O uso de gramíneas na alimentação de capivaras (Hydrochaeris hydrocheris, Linnaeus, 1758) em cativeiro Anais do $7^{\circ}$ Congresso Florestal Brazileiro e $1^{\circ}$ Congresso Florestal Panamericano 70-74

Mills JN, Ellis BA, Mckee KT, Maiztegui JI and Childs JE (1992) Reproductive characteristics of rodent assemblages in cultivated regions of central Argentina Journal of Mammalogy 73 515-526

Morin LP (1986) Environment and hamster reproduction: responses to phase-specific starvation during estrous cycle American Journal of Physiology 251 R663-R669

Ojasti J (1972) El Chigüire Ministerio de Agricultura y Cria Oficina de Divulgação Agrícola, Caracas

Parra R, Escobar A and Gonzalez E (1978) El Chiguire su potencial biologico y su cria en confinamiento Informe Anual - IPA 83-94

Randolph JC, Cameron GN and McClure PA (1995) Nutritional requirements for reproduction in the hispid cotton rat, Sigmodon hispidus. Journal of Mammalogy 76 1113-1126

Sadleir MFS (1969) The Ecology of Reproduction in Wild and Domestic Mammals Methuen and Co Ltd, London

Schneider JE, Zhou D and Blum RM (2000) Leptin and metabolic control of reproduction Hormones and Behavior 37 306-326

Smith MH (1971) Food as a limiting factor in the population ecology of Peryomyscus polionotus (Wagner) Annales Zoologici Fennici 8 109-112

Soares MCF (1992) Estudo da estrutura lipídica e funções hipofisárias em ratos normais e submetidos à dieta corenciada em ácidos graxos essenciais Tese de mestrado UFPE, Recife

Thomas MG, Bao B and Williams GL (1997) Dietary fats varying in their fatty acid composition differentially influence follicular growth in cows fed isoenergetic diets Journal of Animal Science 75 2512-2519

Thong FSL and Graham TE (1999) Leptin and reproduction: is it a critical link between adipose tissue, nutrition, and reproduction? Canadian Journal of Applied Physiology 24 317-336

Trujillo EP and Broughton KS (1995) Ingestion of n-3 polyunsaturated fatty acids and ovulation in rats Journal of Reproduction and Fertility $\mathbf{1 0 5}$ 197-203

Vandenbergh JG, Drickamer LC and Colby DR (1972) Social and dietary factors in the sexual maturation of female mice Journal of Reproduction and Fertility 28 397-405

Watts CHS (1970) Effect of supplementary food on breeding in woodland rodents Journal of Mammalogy 51 169-171

Zara JL (1973) Breeding and husbandry of the capybara, Hydrochaeris hydrochaeris, at Evansville Zoo International Zoological Yearbook 13 137

Received 15 October 2002

First decision 20 November 2002.

Revised manuscript received 23 December 2002.

Accepted 2 January 2003. 